\title{
Characterization of 2,5-dihydroxypyridine dioxygenases from Sinorhizobium sp. L1
}

\author{
Laimonas Karvelis, \\ Renata Gasparavičiūtè, \\ Rolandas Meškys* \\ Department of Molecular \\ Microbiology and Biotechnology, \\ Institute of Biochemistry, \\ Vilnius University, \\ Mokslininku st. 12, \\ LT-08662 Vilnius, \\ Lithuania
}

The Sinorhizobium sp. L1 bacteria utilize 3-hydroxypyridine and nicotinic acid by different pathways. The biosynthesis of the 2,5-dihydroxypyridine 5,6-dioxygenase in Sinorhizobium sp. L1 is induced by 3-hydroxypyridine as well as nicotinic acid, however, the distinct isoforms of the enzyme are produced depending on the applied inducer. Both isoforms of the enzyme have been purified and characterized. A $10.4 \mathrm{~kb}$ DNA fragment has been cloned from Sinorhizobium sp. L1 by using data of the de novo sequencing of the purified enzymes. According to the nucleotide sequence analysis, the cloned fragment encodes a part of the degradation pathway of nicotinic acid. The orf9 gene has been cloned and expressed in Escherichia coli cells. The cells produce an active 2,5-dihydroxypyridine 5,6-dioxygenase.

Key words: Sinorhizobium sp., 2,5-dihydroxypyridine, 2,5-dihydroxypyridine 5,6-dioxygenase, 3-hydroxypyridine, nicotinic acid

\section{INTRODUCTION}

The pyridine ring is the basic structure of widely distributed compounds such as dyes, industrial solvents, herbicides, and pesticides. The pyridine ring is a major constituent of natural plant alkaloids and coenzymes such as nicotinamides. Pyridine compounds can be used by various microorganisms as a carbon, nitrogen and energy source via special catabolic pathways (Fetzner, 2000; Kaiser et al., 1996).

Catabolism and initial hydroxylation steps of monocarboxylated pyridines such as 2-car-

\footnotetext{
*Corresponding author. E-mail: rolandas.meskys@bchi.vu.lt
}

boxypyridine (picolinic acid) (Kiener et al., 1993; Siegmund et al., 1990; Tate, Ensing, 1974), 3-carboxypyridine (nicotinic acid) (Nagel, Andreesen, 1989; Nakano et al., 1999; Ueda, Sashida, 1998) and 4-carboxypyridine (isonicotinic acid) (Kretzer et al., 1993; Singh, Shukla, 1986) have been studied in detail. Nicotinate dehydrogenases, catalyzing the hydroxylation reactions, were purified from Bacillus niacini (Nagel, Andreesen, 1990), Pseudomonas fluorescens TN5 (Hurh et al., 1994), Eubacterium barkeri (previously Clostridium barkeri) (Gladyshev et al., 1996), Ralstonial Burkholderia strain DSM 6920 (Schräder et al., 2002) and Pseudomonas putida KT2440 (Jimenez et al., 2008). Isonicotinate dehydrogenase 
was purified from Mycobacterium sp. INA1 (Kretzer et al., 1993) and picolinic acid 6-hydroxylase was purified and characterized from Arthrobacter picolinophilus (Tate, Ensing, 1974).

2,5-Dihydroxypyridine is an intermediate metabolite, a formation of which is observed during aerobic degradation of some pyridine compounds including nicotinic acid and nicotine (Fetzner, 2000; Kaiser et al., 1996; Jimenez et al., 2008). The oxidative cleavage of 2,5-dihydroxypyridine catalyzed by 2,5-dihydroxypyridine 5,6-dioxygenase is an important catabolic step starting a maleamic pathway (Jimenez et al., 2008).

Unfortunately, there are no data about characterized enzyme or / and genes involved in the transformation of 3-hydroxypyridine by microorganisms. Recently we have isolated the Sinorhizobium sp. L1 bacteria capable to utilize both 3-hydroxypyridine and nicotinic acid as a single carbon and energy source (Karvelis, Meškys, 2004). In this study, we are demonstrating that the biosynthesis of 2,5-dihydroxypyridine 5,6dioxygenase in Sinorhizobium sp. L1 is induced by 3-hydroxypyridine as well as nicotinic acid, however, the different isoforms of the enzyme are produced depending on the applied inducer. We have been able to identify and characterize a gene cluster encoding a part of the nicotinic acid degradation pathway in Sinorhizobium sp. L1. In addition, a recombinant 2,5-dihydroxypyridine 5,6-dioxygenase has been expressed Escherichia coli.

\section{MATERIALS AND METHODS}

Chemicals. Nicotinic, 6-hydroxynicotinic acids and 3-hydroxypyridine were obtained from Merck. 2,5-Dihydroxypyridine was synthesized according to (Berhman, Pitt, 1958).

Bacterial strains. Sinorhizobium sp. L1, capable to degrade 3-hydroxypyridine and pyridine-3-carboxylic acid was described previously (Karvelis, Meškys, 2004). Escherichia coli DH5a ( $\$ 80$ dlacZ $\Delta$ M15 $\Delta$ (lacZY-argF) U169, deoR, recA1, endA1, hsdR17 $\left(\mathrm{r}_{\mathrm{K}}{ }^{-} \mathrm{m}_{\mathrm{K}}{ }^{+}\right)$, dup E44, thi-1, gyrA96, relA1) was obtained from Pharmacia, E. coli BL21 F-, omp T, gal, hsd $\mathrm{S}_{\mathrm{B}}\left(\mathrm{r}_{\mathrm{B}}{ }^{-} \mathrm{m}_{\mathrm{B}}{ }^{-}\right), d c m$, lon (DE3) from Avidis.

Bacterial vectors. pUC19/PstI, pUC19/SalI, pUC19/HindIII, pUC19, and pTZ57R/T were ob- tained from Fermentas Thermofisher; pET19 was obtained from Invitrogen.

Media and growth conditions: Sinorhizobium sp. L1 cells were grown in the EFA medium, (g/l): $\mathrm{K}_{2} \mathrm{HPO}_{4}-8.8,\left(\mathrm{NH}_{4}\right)_{2} \mathrm{SO}_{4}-1.0, \mathrm{NaCl}-2.35$, yeast extract $-0.5, \mathrm{MgSO}_{4} \times 7 \mathrm{H}_{2} \mathrm{O}-0.18$, salt solution $-10 \mathrm{ml} / \mathrm{l}$; salt solution $(\mathrm{g} / \mathrm{l}): \mathrm{CaCl}_{2} \times 2 \mathrm{H}_{2} \mathrm{O}-2.0$, $\mathrm{MnSO}_{4} \times 4 \mathrm{H}_{2} \mathrm{O}-1.0, \mathrm{FeSO}_{4} \times 7 \mathrm{H}_{2} \mathrm{O}-0.6$ $\mathrm{NaMoO}_{4} \times 2 \mathrm{H}_{2} \mathrm{O}-0.5$, all components were dissolved in $0.1 \mathrm{~N} \mathrm{HCl}$ and added to EFA1 medium before cultivation. Nutrient Broth and Nutrient Agar (NA) (Oxoid) were used for cultivation of E. coli cells. All media and solutions were autoclaved at $1 \mathrm{~atm}$ for $30 \mathrm{~min}$. E. coli was cultivated at $37^{\circ} \mathrm{C}$, Sinorhizobium sp. L1 was cultivated at $30^{\circ} \mathrm{C}$. In liquid medium, bacteria were cultivated with aeration and shaking at $180 \mathrm{rpm}$.

DNA isolation and manipulation. Total DNA from Sinorhizobium sp. L1was isolated by method proposed by Woo et al. (18). Plasmid DNA from E. coli was isolated by alkaline lysis method (Maniatis et al., 1982). Restriction endonucleases, phosphotase (FastAP), T4 DNA ligase were purchased from Fermentas Thermofisher and used as recommended. DNA for sequencing was purified using ZYMO Plasmid MiniPREP (Zymo Research). E. coli cells were prepared for electroporation by the method of Sharma \& Schimke (Sharma, Schimke, 1996). Electroporation into $100 \mu \mathrm{l}$ of the cells was performed using electroporator 2510 (Eppendorf, Germany) with electrical conditions selected as $2.0 \mathrm{kV} / \mathrm{cm}$ and impulse duration of 5.0-5.6 ms. Transformed E. coli bacteria were incubated at $37^{\circ} \mathrm{C}$ for 1 hour, thereafter cells were spread on solid NA with ampicillin.

DNA sequencing and analysis. Primers for nicotinic acid degradation operon genes were designed using de novo sequences of peptides. The sequencing was performed at Macrogen (South Korea). Vector NTI 9.0 (Gorelenkov et al., 2001) was used for DNA and protein analysis. The nearest homologues for phylogenetic analysis of proteins were picked by using the BLAST family programs (NCBI) (Altschul et al., 1990).

Resting cells reactions. Sinorhizobium sp. L1 cells were pre-grown in $20 \mathrm{~mL}$ of EFA medium, containing the appropriate pyridine compound at $30{ }^{\circ} \mathrm{C}$ overnight with aeration. Cells were transferred into the $50 \mathrm{~mL}$ of the same media, and 
the cultivation continued for next 24-48 hours. The cells were harvested by centrifugation at $10000 \mathrm{~g}$ for 20 minutes and washed twice with $50 \mathrm{mM}$ potassium phosphate buffer ( $\mathrm{pH}$ 7.2). The washed cells were suspended in the $1 \mathrm{~mL}$ of the same buffer, and the $0.1-0.2 \mathrm{mM}$ of substrate was added. Cells were resuspended and immediately harvested by centrifugation. The supernatant was transferred to the quartz cuvette, and the primary spectrum was read over a range of 200 to $400 \mathrm{~nm}$. Later, the supernatant and the harvested cells were transferred to the same reaction cell and further incubated. The spectra were recorded in appropriate time intervals after centrifugation of cells, using Helios $\gamma$ spectrophotometer (Thermo).

Preparation of cell-free extracts. The cells grown in the liquid media were harvested by centrifugation and washed twice with $20 \mathrm{mM}$ potassium phosphate buffer ( $\mathrm{pH} 7.0$ ), then resuspended in the same buffer, and disrupted by sonication at $22 \mathrm{kHz}$. The cells debris was removed by centrifugation (12000 $\mathrm{g}$ for $20 \mathrm{~min}$ ).

Enzyme assays. Activity of 2,5-dihydroxypyridine 5,6-dioxygenase was analyzed as described previously (Gauthier, Rittenberg, 1971). One unit of activity was defined as the amount of enzyme necessary to oxidize $1 \mu \mathrm{mol}$ of 2,5-dihydroxypyridine per min. Activity of nicotinate dehydrogenase was analyzed as described previously (Jimenez et al., 2008). One unit of activity was defined as the amount of enzyme necessary to oxidize $1 \mu \mathrm{mol}$ of nicotinate per min. Other enzymes were detected as described previously (Jimenez et al., 2008; Gauthier, Rittenberg, 1971).

Protein de novo sequencing. The proteins were extracted from the polyacrylamide gel after separation. Samples were prepared for the mass spectrometry analysis according to the specifications of the Proteomics Centre at the Institute of Biochemistry, Vilnius University. The mass spectra were analyzed using the GPS Explorer ${ }^{\mathrm{rt}}$ De Novo Explorer program.

\section{RESULTS AND DISCUSSION}

The Sinorhizobium sp. L1 bacteria were isolated previously as 3-hydroxypyridine-degrading organism (Karvelis, Meškys, 2004). The analysis of substrate specificity showed that this microorganism could utilize various compounds as a substrate (Table 1). Moreover, the different combinations of catabolic enzymes were induced in the presence of the appropriate carbon sources (Table 1). The utilization of 3-hydroxypyridine was always accompanied by formation of green pigment which turned brown. A more detailed analysis of utilization of nicotinic acid showed it was degraded by the formation of 2,5-dihydroxypyridine. The detected enzymatic activities supported this conclusion (Table 1). However, the growth in the presence of nicotinic acid was not accompanied by the pigment formation, notwithstanding that the metabolic pathway proceeded via biosynthesis of 2,5-dihydroxypyridine. Hence, it was

Table 1. The detected enzymes in the Sinorhizobium sp. L1 cell-free extracts. The bacteria were grown in mineral media containing an appropriate carbon source (final concentration $0.2 \%) .(+)$ - the activity was detected, $(-)$ - no activity was detected, $( \pm)$ - a very weak activity

\begin{tabular}{c|c|c|c|c|c|c}
\hline & \multicolumn{7}{c}{ Carbon source } \\
\cline { 2 - 6 } Enzyme activity & $\begin{array}{c}\text { Succinic } \\
\text { acid }\end{array}$ & $\begin{array}{c}\text { Nicotin- } \\
\text { amide }\end{array}$ & $\begin{array}{c}\text { 6-Hydroxy- } \\
\text { nicotinic } \\
\text { acid }\end{array}$ & $\begin{array}{c}\text { Nicotinic } \\
\text { acid }\end{array}$ & $\begin{array}{c}\text { 3-Hydro- } \\
\text { xypyridine }\end{array}$ & $\begin{array}{c}\text { 3-Hydroxy- } \\
\text { methyl- } \\
\text { pyridine }\end{array}$ \\
\hline $\begin{array}{c}\text { Nicotinamide } \\
\text { deaminase }\end{array}$ & - & + & - & - & - \\
\hline $\begin{array}{c}\text { Nicotinate } \\
\text { dehydrogenase }\end{array}$ & - & + & + & + & + & + \\
\hline $\begin{array}{c}\text { 6-Hydroxynicotinate } \\
\text { 3-monooxygenase }\end{array}$ & - & + & + & + & + \\
\hline $\begin{array}{c}\text { 2,5-Dihydroxypyri- } \\
\text { dine 5,6-dioxygenase }\end{array}$ & + & + & + & + & + \\
\hline $\begin{array}{c}\text { Maleamic acid } \\
\text { deaminase }\end{array}$ & + & + & + & + & + \\
\hline
\end{tabular}


proposed that 3-hydroxypyridine and nicotinic acid induced the different catabolic pathways. The presence of different regulation systems was confirmed by investigation of resting Sinorhizobium sp. L1 cells. The cells pre-grown in the media containing 3-hydroxypyridine could degrade 3-hydroxypyridine and 2,5-dihydroxypyridine only. No bioconversion was observed with the nicotinic acid. Vice versa, the cells pre-grown in the presence of the nicotinic acid were able to degrade the nicotinic and 2,5-dihydroxypyridine, but 3-hydroxypyridine was not attacked.

The analysis of the cell-free extract showed that 2,5-dihydroxypyridine 5,6-dioxygenase is induced both in the presence of 3-hydroxypyridine and nicotinic acid. To elucidate whether the same or the distinct forms of dioxygenase were produced, the 2,5-dihydroxypyridine 5,6-dioxygenases were purified from differently induced biomass of $\mathrm{Si}$ norhizobium sp. L1. The results are presented in Tables 2 and 3.

The SDS-PAGE analysis showed that the purified proteins were almost homogeneous (Fig. 1, lanes 2 and 3), but differed in molecular masses of subunits. The 3-hydroxypyridine-induced cells of Sinorhizobium sp. L1 produced the 2,5-dihydroxypyridine 5,6-dioxygenase consisting of $39.8 \mathrm{kDa}$ subunits (isoform A) (Fig. 1, lane 3). The molecular mass of the subunit of the 2,5-dihydroxypyridine 5,6-dioxygenase from the nicotinate-induced cells was determined to be $38.3 \mathrm{kDa}$ (isoform $\mathrm{B}$ ) (Fig. 1, lane 2).

The molecular masses of the native enzymes determined by gel-filtration were $230 \pm 2 \mathrm{kDa}$ and $214 \pm 2 \mathrm{kDa}$, respectively. The purified enzymes are similar by molecular masses to 2,5-dihydroxypyridine 5,6-dioxygenase from Pseudomonas putida N-9, KT2440 and S16 (Jimenez et al., 2008; Gauthier, Rittenberg, 1971; Tang et al., 2008).

Both isoforms showed similar catalytic properties. Both enzymes needed oxygen and Fe(II) for the full activity. The optimal $\mathrm{pH}$ for the oxidation of 2,5-dihydroxypyridine by the isoform $\mathrm{A}$ and $\mathrm{B}$ was 7.5-7.75 and 7.25-7.5, accordingly. The $\mathrm{K}_{\mathrm{m}}$ values for 2,5-dihydroxypyridine at $\mathrm{pH} 7.2$ were 175 and $150 \mu \mathrm{M}$ for the isoform $\mathrm{A}$ and $\mathrm{B}$, respectively. Both dioxygenases were inhibited by 2,5-dihydroxypyridine when the substrate concentration was higher than $0.8 \mathrm{mM}$. The enzymes were sensitive to chelators of metal ions. However, the enzymes were different in the specific activity 10 -fold.

The purified enzymes were analyzed by the de novo sequencing. Three peptides identified

Table 2. Purification of 2,5-dihydroxypyridine 5,6-dioxygenase from the nicotinate-induced cells of Sinorhizobium sp. L1

\begin{tabular}{|c|c|c|c|c|c|}
\hline Step & $\begin{array}{c}\text { Total } \\
\text { activity, } \mathrm{U}\end{array}$ & $\begin{array}{c}\text { Total } \\
\text { protein, mg }\end{array}$ & $\begin{array}{c}\text { Specific } \\
\text { activity, } \mathrm{U} / \mathrm{mg}\end{array}$ & $\begin{array}{c}\text { Purification, } \\
\text {-fold }\end{array}$ & $\begin{array}{l}\text { Yield, } \\
\% \\
\end{array}$ \\
\hline Cell-free extract & 5400 & 500 & 11 & 1 & 100 \\
\hline Ultracentrifugation & 3950 & 340 & 11.6 & 1.05 & 73.1 \\
\hline $\begin{array}{c}\text { 30-40\% ammonium } \\
\text { sulphate }\end{array}$ & 2280 & 115 & 19.8 & 1.8 & 44.2 \\
\hline GigaCapQ & 1760 & 19 & 92.6 & 8.4 & 32.6 \\
\hline Resource 15PHE & 430 & 1.4 & 307 & 27.9 & 8 \\
\hline Resource 15Q & 320 & 0.64 & 500 & 45.5 & 5.9 \\
\hline
\end{tabular}

Table 3. Purification of 2,5-dihydroxypyridine 5,6-dioxygenase from the 3-hydroxypyridine-induced cells of Sinorhizobium sp. L1

\begin{tabular}{c|c|c|c|c|c}
\hline Step & $\begin{array}{c}\text { Total } \\
\text { activity, U }\end{array}$ & $\begin{array}{c}\text { Total } \\
\text { protein, mg }\end{array}$ & $\begin{array}{c}\text { Specific } \\
\text { activity, U/mg }\end{array}$ & $\begin{array}{c}\text { Purification, } \\
\text {-fold }\end{array}$ & $\begin{array}{c}\text { Yield, } \\
\%\end{array}$ \\
\hline Cell-free extract & 385 & 192.5 & 2 & 1 & 100 \\
\hline $\begin{array}{c}\text { 30-40\% ammonium } \\
\text { sulphate }\end{array}$ & 210 & 97 & 2.2 & 1.1 & 54.5 \\
\hline GigaCapQ & 180 & 23 & 7.8 & 3.9 & 46.7 \\
\hline Resource 15PHE & 27 & 1.1 & 24.5 & 12.25 & 7 \\
\hline Resource 15Q & 19 & 0.32 & 59.4 & 29.7 & 4.9 \\
\hline
\end{tabular}




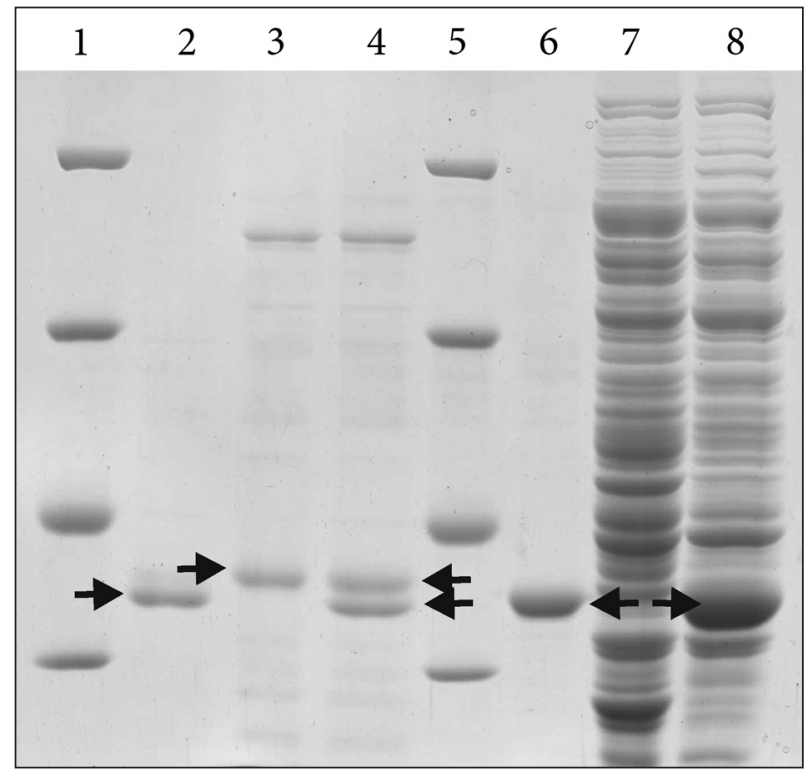

Fig. 1. The SDS-PAGE analysis of 2,5-dihydroxypyridine 5,6-dioxygenases from Sinorhizobium sp. L1. 1) and 5) protein ladder (from top to bottom 116, 66.2, 45 and $35 \mathrm{kDa}$ ); 2) the purified 2,5-dihydroxypyridine 5,6-dioxygenase from 3-hydroxypyridine-induced cells of $\mathrm{Si}$ norhizobium sp. L1;3) the purified 2,5-dihydroxypyridine 5,6-dioxygenase from nicotinateinduced cells of Sinorhizobium sp. L1;4) the mixture of samples 2 and 3;6) the purified recombinant 2,5-dihydroxypyridine 5,6-dioxygenase from cells of E. coli BL21(DE3); 7) the control, cell-free extract of E. coli BL21(DE3); 8) the cell-free extract of E. coli BL21(DE3) / pET19orf9. 2,5-Dihydroxypyridine 5,6-dioxygenases are marked by small arrows

in the 2,5-dihydroxypyridine 5,6-dioxygenase A had the following sequences IITAVEPPEIIAR, MMPYPELR, and PYPELR. In addition, IDYADAFIAAGKR, VITAVEPAPLIGR, WDHGEPAAF, and VVVISKGDER peptides were identified in the isoform B. The BLAST analysis showed that three of them of the isoform B were homologous to the hypothetical protein (YP_002978554) from Rhizobium leguminosarum bv. trifolii WSM1325. The corresponding degenerated oligonucleotides based on this protein encoding gene sequence as well as de novo sequencing data were synthesized. The 685 bp DNA fragment was amplified using the developed oligonucleotides and total DNA from Sinorhizobium sp. L1. The pF1R4A plasmid containing this fragment was constructed and the DNA sequence of the cloned insert was determined. The BLAST analysis showed that the amplified DNA was most homologous to genes of 2,5-dihydroxypyridine 5,6-dioxygenases from various microorganisms. The full gene, encoding 2,5-dihydroxypyridine 5,6-dioxygenase was identified by screening the gene library of Sinorhizobium sp. L1 using the oligonucleotides adapted to the determined sequence of the $685 \mathrm{bp}$ DNA fragment. One clone harboring the pL1Pst25 plasmid containing a 10.3-kb DNA insert and resulting in a positive PCR reaction was selected for further analysis.

Sequence analysis of the cloned DNA fragment from pL1Pst25 revealed eleven putative ORFs (Fig. 2). The Shine-Dalgarno sequences were de-

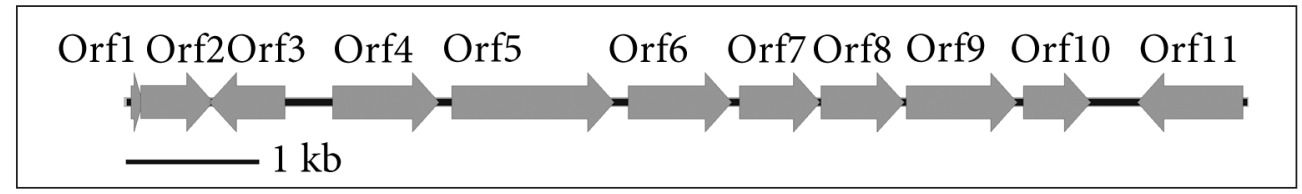

Fig. 2. Graphical representation of the DNA fragment (10351 bp) from Sinorhizobium sp. L1 cloned in the pL1Pst25 plasmid 
Table 4. Summary of ORFs identified by significant homology in pL1Pst25 plasmid

\begin{tabular}{|c|c|c|c|c|}
\hline ORF & $\begin{array}{l}\text { Length, } \\
\text { (a.a.) }\end{array}$ & Nearest homolog & $\begin{array}{l}\text { GenBank Ac- } \\
\text { cession No. }\end{array}$ & E value \\
\hline Orf1 & 35 & $\begin{array}{l}\text { carbon-monoxide dehydrogenase, } \\
\text { Rhodopseudomonas palustris HaA2 }\end{array}$ & ABD07809 & $6 \mathrm{E}-06$ \\
\hline Orf2 & 224 & $\begin{array}{c}\text { hypothetical protein CTS44_14338 } \\
\text { Comamonas testosteroni S44 }\end{array}$ & EFI60974 & $9 \mathrm{E}-81$ \\
\hline Orf3 & 233 & $\begin{array}{l}\text { GntR family transcriptional regulator } \\
\text { Comamonas testosteroni } \mathrm{S} 44\end{array}$ & EFI60973 & $6 \mathrm{E}-32$ \\
\hline Orf4 & 329 & $\begin{array}{l}\text { hypothetical periplasmic protein } \\
\text { TorT Marinomonas sp. MED121 }\end{array}$ & EAQ65112 & $3 \mathrm{E}-86$ \\
\hline Orf5 & 503 & $\begin{array}{c}\text { sugar ABC transporter ATP-binding } \\
\text { protein Marinomonas sp. MED121 }\end{array}$ & EAQ65113 & $3 \mathrm{E}-172$ \\
\hline Orf6 & 290 & $\begin{array}{l}\text { Ribose / xylose / arabinose / galactoside } \\
\text { ABC-type transport systems, permease } \\
\text { component Marinomonas sp. MED121 }\end{array}$ & EAQ65114 & $6 \mathrm{E}-90$ \\
\hline Orf7 & 249 & $\begin{array}{c}\text { maleate cis-trans isomerase } \\
\text { Pseudomonas putida S16 }\end{array}$ & ADN26549 & $2 \mathrm{E}-148$ \\
\hline Orf8 & 257 & $\begin{array}{l}\text { hydrolase (deformylase), alpha / beta fold } \\
\text { family Octadecabacter antarcticus } 238\end{array}$ & EDY88475 & $7 \mathrm{E}-137$ \\
\hline Orf9 & 343 & $\begin{array}{c}\text { 2,5-dihydroxypyridine 5,6-dioxygenase } \\
\text { Pelagibacterium halotolerans B2 }\end{array}$ & AEQ53770 & 0.0 \\
\hline Orf10 & 208 & $\begin{array}{l}\text { N-carbamoylsarcosine amidase } \\
\text { Pelagibacterium halotolerans B2 }\end{array}$ & AEQ53771 & $7 \mathrm{E}-110$ \\
\hline Orf11 & 327 & $\begin{array}{l}\text { putative formaldehyde dehydrogenase, } \\
\text { glutathione-independent Dermacoccus sp. } \\
\text { Ellin } 185\end{array}$ & EFP57883 & $2 \mathrm{E}-104$ \\
\hline
\end{tabular}

tected in the upstream regions of deformylase (GAGAGGGCGAGATG) and 2,5-dihydroxypyridine 5,6-dioxygenase genes (GAGAGGAAATAGCGCGATG).

Four of OFRs (Orf6, Orf7, Orf8, Orf9) shared the significant sequence homology with enzymes participating in the biodegradation of nicotinic acid (Jimenez et al., 2008). The predicted functions of ORFs from pL1Pst 25 are presented in Table 4. The comparison of gene organization in pL1Pst 25 plasmid and the similar gene clusters from other bacteria showed that the genes encoding the degradation of 2,5-dihydroxypyridine from Sinorhizobium sp. L1 differed from the well characterized nic operon from Pseudomonas putida KT2440 (Jimenez et al., 2008). Hence, the transport system proteins were rarely present in the nic related gene clusters, but these clusters usually contained 6-hydroxynicotinate 3-monooxygenase gene located near the core genes consisting of maleate isomerase, $\mathrm{N}$-formylmaleamate deformylase, 2,5dihydroxypyridine dioxygenase and maleamate amidase encoding sequences.
To clarify a function of the orf9 gene it was cloned into pET19 expression vector and the protein synthesis was induced in E. coli BL21 (DE3) cells (Fig. 1, lane 8) using standard molecular techniques. Most of protein was produced in the inclusion bodies, but part of the recombinant 2,5dihydroxypyridine dioxygenase remained soluble. The soluble protein was purified to homogeneity (Fig. 1, lane 7) and showed an expected activity in the presence of 2,5-dihydroxypyridine. Moreover, the SDS-PAGE analysis of the purified recombinant 2,5-dihydroxypyridine 5,6-dioxygenase led to conclusion that the protein was the isoform $\mathrm{B}$ (Fig. 1, lane 6). This observation strengthens the conclusion that the cloned DNA fragment encodes the part of the nicotinic acid degradation operon in Sinorhizobium sp. L1.

\section{CONCLUSION}

Sinorhizobium sp. L1 cells utilized 3-hydroxypyridine and nicotinic acid via formation of 2,5-dihydroxypyridine, which was subsequently 
oxidized by different 2,5-dihydroxypyridine 5,6dioxygenase isoforms, depending on the metabolic pathway. For the first time the gene encoding 2,5-dihydroxypyridine 5,6-dioxygenase from Sinorhizobium spp. was expressed in E. coli BL21 (DE3) cells and the active recombinant enzyme was purified.

\section{ACKNOWLEDGEMENT}

This research was funded by a grant (No. MIP076/2011) from the Research Council of Lithuania.

Received 24 July 2012 Accepted 28 August 2012

\section{References}

1. Altschul SF, Gish W, Miller W, Myers EW, Lipman DJ. Basic local alignment search tool. J Mol Biol 1990; 215: 403-10.

2. Berhman EJ, Pitt BM. The Elbs peroxydisulphate oxidation in the pyridine series: a new synthesis of 2,5-dihydroxypyridine. J Am Chem Soc 1958; 80: $3717-18$.

3. Fetzner S. Enzymes involved in the aerobic bacterial degradation of $\mathrm{N}$-heteroaromatic compounds: molybdenum hydroxylases and ringopening 2,4-dioxygenases. Naturwissenschaften 2000; 87: 59-69.

4. Gauthier JJ, Rittenberg SC. The metabolism of nicotinic acid. I. Purification and properties of 2,5-dihydroxypyridine oxygenase from $\mathrm{Pseu}$ domonas putida N-9. J Biol Chem 1971; 246: 3737-42.

5. Gladyshev VN, Khangulov SV, Stadtman TC. Properties of the selenium- and molybdenumcontaining nicotinic acid hydroxylase from Clostridium barkeri. Biochem 1996; 35: 212-23.

6. Gorelenkov V, Antipov A, Lejnine S, Daraselia N, Yuryev A. Set of novel tools for PCR primer design. Biotechniques 2001; 31: 1326-30.

7. Hurh B, Yamane T, Nagasawa T. Purification and characterization of nicotinic acid dehydrogenase from Pseudomonas fluorescens TN5. J Ferment Bioeng 1994; 78: 19-26.

8. Jimenez JI, Canales A, Barbero JJ, Gilanski K, Rychlewski L, Garcia JL, Diaz E. Deciphering the genetic determinants for aerobic nicotinic acid degradation: the nic cluster from Pseudomonas putida KT2440. PNAS 2008; 105: 11329-34.

9. Kaiser JP, Feng Y, Bollag JM. Microbial metabolism of pyridine, quinoline, acridine, and their derivatives under aerobic and anaerobic conditions. Microbiol Rev 1996; 60: 483-98.

10. Karvelis L, Meškys R. New Rhizobium strain, degrading 3-hydroxypyridine. Biologija 2004; 2: 98-101.

11. Kiener A, Glockler R, Heinzmann K. Preparation of 6-oxo-1,6-dihydropyridine-2-carboxylic acid by microbial hydroxylation of pyridine-2carboxylic acid. J Chem Soc Perkin Trans 1993; 1: 1201-2.

12. Kretzer A, Frunzke K, Andreesen JR. Catabolism of isonicotinate by Mycobacterium sp. INA1: extended description of the pathway and purification of the molybdoenzyme isonicotinate dehydogenase. J Gen Microbiol 1993; 139: 2763-72.

13. Maniatis T, Fritsch EF, Sambrook J. Molecular cloning: a Laboratory Manual. Cold Spring Harbor, NY: Cold Spring Harbor Laboratory. 1982.

14. Nagel M, Andreesen JR. Molybdenum-dependent degradation of nicotinic acid by Bacillus sp. DSM 2923. FEMS Microbiol Lett 1989; 59: $147-$ 52.

15. Nagel M, Andreesen JR. Purification and characterization of the molybdoenzymes nicotinate dehydrogenase and 6-hydroxynicotinate dehydrogenase from Bacillus niacini. Arch Microbiol 1990; 154: 605-13.

16. Nakano H, Wieser M, Hurh B, Kawai T, Yoshida T, Yamane T, Nagasawa T. Purification, characterization and gene cloning of 6-hydroxynicotinate 3-monooxygenase from Pseudomonas fluorescens TN5. Eur J Biochem 1999; 260: 120-6.

17. Schräder T, Thiemer B, Andreesen JR. A molybdenum-containing dehydrogenase catalyzing an unusual 2-hydroxylation of nicotinic acid. Appl Microbiol Biotechnol 2002; 58: 612-7.

18. Sharma RC, Schimke RT. Preparation of electrocompetent $E$. coli using salt-free growth medium. Biotechniques 1996; 20: 42-4.

19. Siegmund I, Koenig K, Andreesen JR. Molybdenum involvement in aerobic degradation of picolinic acid by Arthrobacter picolinophilus. FEMS Microbiol Lett 1990; 67: 281-4. 
20. Singh RP, Shukla OP. Isolation, characterization and metabolic activities of Bacillus brevis degrading isonicotinic acid. J Ferment Technol 1986; 64: 109-17.

21. Tang $H$, Wang S, Ma L, Meng X, Deng Z, Zhang D, Ma C, Xu P. A novel gene, encoding 6-hydroxy-3-succinoylpyridine hydroxylase, involved in nicotine degradation by Pseudomonas putida strain S16. Appl Env Microbiol 2008; 74: 1567-74.

22. Tate RL, Ensign JC. Picolinic acid hydroxylase of Arthrobacter picolinophilus. Can J Microbiol 1974; 20: 695-702.

23. Ueda M, Sashida R. Microbial production of 2-hydroxynicotinic acid from nicotinic acid by intact cells of MCI3289. J Mol Catal B 1998; 4: 199-204.

24. Woo TH, Cheng AF, Ling JM. An application of a simple method for the preparation of bacterial DNA. Biotechniques 1992; 13: 696-8.

\section{Laimonas Karvelis, Renata Gasparavičiūtė,} Rolandas Meškys

\section{SINORHIZOBIUM SP. L1 2,5-DIHIDROKSI- PIRIDINO 5,6-DIOKSIGENAZIŲ CHARAKTERIZAVIMAS}

\section{Santrauka}

Nustatyta, kad 3-hidroksipiridino ir nikotino rūgšties skaidymas Sinorhizobium sp. L1 ląstelèse vyksta skirtingais keliais. Pastebèta, kad Sinorhizobium sp. L1 ląstelèse 3-hidroksipiridinas ir nikotino rūgštis indukuoja skirtingas 2,5-dihidroksipiridino 5,6-dioksigenazès izoformas. Abi fermento izoformos buvo išgrynintos ir charakterizuotos. Panaudojus baltymų de novo sekvenavimo metodą, buvo klonuotas 10,4 kb DNR fragmentas iš Sinorhizobium sp. L1. Nukleotidų sekos analizè rodo, kad klonuotas fragmentas koduoja dali nikotino rūgšties degradacijos kelio. Klonavus orf9 geną Escherichia coli ląstelèse, buvo stebèta aktyvios rekombinantinès 2,5-dihidroksipiridino 5,6-dioksigenazès raiška.

Raktažodžiai: Sinorhizobium sp., 2,5-dihidroksipiridinas, 2,5-dihidroksipiridino 5,6-dioksigenazè, 3-hidroksipiridinas, nikotino rūgštis 